\title{
REGIONAL DIFFERENCES IN THE NUMBER AND TYPE OF MYENTERIC NEURONS OF THE ILEUM OF RATS
}

\section{A comparison of techniques of the neuronal evidentiation}

\author{
Marcílio Hubner Miranda-neto a', Sonia Lucy Molinaria2, \\ Maria Raquel Marçal Natalia3, Debora de Melo Gonçalves Sant'Ana ${ }^{a, b 4}$
}

\begin{abstract}
We carried out this study with the purpose of analyzing the density of neurons of the myenteric plexus in the mesenteric, intermediate and antimesenteric regions of the ileum of rats. Whole-mounts stained with four different techniques were employed. Through countings under optic microscope in an area of 8.96 $\mathrm{mm}^{2}$ we found the following neuronal means with the techniques of Giemsa, NADH-diaphorase histochemistry, NADPH-diaphorase and acetylcholinesterase, respectively: mesenteric region $2144.40 \pm 161.05,1657.80 \pm 88.23$, $473.80 \pm 19.62,905.25 \pm 22.40$; intermediate region $1790.60 \pm 128.24,1265.20 \pm 141.17,371.30 \pm 27.84$, $770.25 \pm 33.12$; antimesenteric region $1647.0 \pm 76.67,981.80 \pm 68.04,298.50 \pm 22.75,704.50 \pm 69.38$. We conclude that there is a variation of neuronal density around the intestinal circumference and this fact independs on the technique used to stain the neurons, and that in a single region the neuronal density varies with the technique employed. We also call attention for the identification of the site were countings were carried out, so that the results of research in this area are not compromised.
\end{abstract}

KEY WORDS: myenteric plexus, Giemsa, NADPH-diaphorase, NADH-diaphorase, acetylcholinesterase, rat, ileum.

Diferenças regionais no número e tipo de neurônios mientéricos do íleo de ratos: comparação entre técnicas de evidenciação neuronal

RESUMO - Realizamos este estudo com o objetivo de analisar a densidade de neurônios do plexo mientérico nas regiões mesentérica, intermediária e antimesentérica do íleo de ratos. Empregamos preparados de membrana corados por 4 diferentes técnicas. Através de contagens sob microscópio óptico em uma área de $8,96 \mathrm{~mm}^{2}$ encontramos com as técnicas de Giemsa, histoquímica da NADH-diaforase, NADPH-diaforase e acetilcolinesterase, respectivamente as seguintes médias neuronais: região mesentérica 2144,40 161,05 , $1657,80 \pm 88,23,473,80 \pm 19,62,905,25 \pm 22,40$; região intermediaria $1790,60 \pm 128,24,1265,20 \pm 141,17$, $371,30 \pm 27,84,770,25 \pm 33,12$; região antimesentérica 1647,0 $\pm 76,67,981,80 \pm 68,04,298,50 \pm 22,75$, $704,50 \pm 69,38$. Concluimos que há uma variação na densidade neuronal ao redor da circunferência intestinal, e este fato independe da técnica utilizada para marcar os neurônios, e que em uma mesma região, a densidade neuronal varia com a técnica utilizada. Também chamamos a atenção para que seja indicado o local onde as quantificações serão realizadas, para que não haja comprometimento dos resultados em pesquisa nesta área.

PALAVRAS-CHAVE: plexo mientérico,Giemsa, NADPH-diaforase, NADH-diaforase, acetilcolinesterase, ratos, íleo.

In the vast literature on enteric neurons, it is common to find out divergences concerning the density of cell bodies verified by the authors in the same segment or in different segments of the digestive tube of animals from the same or from different species $^{1-3}$.

In a single species, several neuronal densities are found when the same segment of the digestive tract of animals of different ages ${ }^{4-6}$, or subjected to varied experimental conditions ${ }^{7,8}$, are compared. These differences are even more striking when the techniques of neuronal staining are distinct ${ }^{9-13}$.

Several authors call into attention that the neuronal density can also vary in a single segment of the gut when different regions of the intestinal circumference are compared ${ }^{1,4,6,11}$.

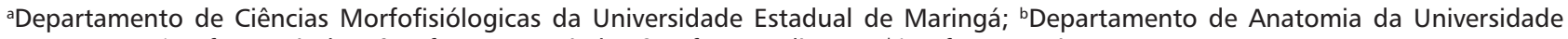

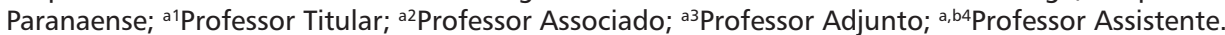

Received 21 July 2000, received in final form 9 October 2000. Accepted 19 October 2000.

Prof. Dr. Marcílio Hubner de Miranda Neto - Universidade Estadual de Maringá -Av. Colombo 5790 Bloco H-79 - 87020-900 - Maringá PR - Brasil. 
Considering the complexity of the myenteric plexus and the increasing interest in the study of its neurons, as well as the importance of knowing details about the distribution of the neuronal populations and subpopulations that it comprises, we carried out this research with the purpose of analyzing the neuronal density in the mesenteric, intermediate and antimesenteric regions of the ileum of rats, using the techniques of Giemsa, NADH-diaphorase (NADHd), NADPH-diaphorase (NADPH-d) and acetylcholinesterase histochemistry. In this way we aim at providing information on quantitative aspects of the distribution of the neurons in this plexus.

\section{METHOD}

Eighteen male rats (Rattus norvegicus), Wistar strain, aging seven months (weight $452.9 \pm 21.21 \mathrm{~g}$ ), from the Central Biotery of the State University of Maringá, were used. The animals were kept in individual cages and received Nuvilab ${ }^{\circledR}$ ration and water ad libitum.

The animals were killed through ethylic ether inhalation. The small intestine was removed and $6 \mathrm{~cm}$ long segments from the terminal ileum were collected. The segments of five animals were washed in $0.9 \%$ saline solution, filled and immersed in fixative solution of acetic formol for 48 hours, then dissected and stained with Giemsa staining solution (methylene blue) in Sorensen phosphate buffer $(\mathrm{pH} 7.0)^{14}$.

The ileum of another five animals were washed and filled with Krebs solution ( $\mathrm{pH}$ 7.3), washed twice (10 min each wash) in Krebs and immersed for five min in Triton $\mathrm{X}-100{ }^{\circledR} 0.3 \%$ in Krebs. Then they were washed twice (10 min each wash) in Krebs solution and incubated for 45 min for evidenciation of the NADH-d. This solution contained (for $100 \mathrm{ml}$ ): $25 \mathrm{ml}$ of Nitro Blue Tetrazolium (NBT: Sigma, St. Louis, USA) storage solution at $0.5 \% ; 25 \mathrm{ml}$ of $0.1 \mathrm{M}$ phosphate buffer $\mathrm{pH} 7.3 ; 50 \mathrm{ml}$ distilled water; and $50 \mathrm{mg}$ of $\beta$-NADH (Sigma, Steinheim, Germany) ${ }^{15}$.

The ileum of four animals were washed and filled with phosphate buffer (PB, pH 7.4), fixed in 4\% paraformaldehyde (Merck, Darmstadt, Germany) prepared in phosphate buffer $0.1 \mathrm{M}$ (PB, pH 7.4) for $30 \mathrm{~min}$, immersed in $0.3 \%$ Triton $\mathrm{X}-100^{\circledR}$ (Sigma, St. Louis, USA) dissolved in saline phosphate buffer (PBS, pH 7.4) for $10 \mathrm{~min}$ and then washed 10 times (10 min each wash) in PBS and incubated for the evidenciation of the NADPH-d according to SchererSingler et al ${ }^{16}$, for two hours. This medium contained (for each $200 \mathrm{ml}$ ): NBT 50 mg, $\beta$-NADPH (Sigma, Steinheim, Germany) 100 mg, Triton $\mathrm{X}-100^{\circledR} 0.3 \%$ In Tris-HCl buffer (GibcoBRL, N.Y., USA) $0.1 \mathrm{M}$ (pH 7.6). After incubation the samples were opened at the mesenteric attachment and washed three times in PBS for five min, and then immersed in $4 \%$ paraformaldehyde solution.

For the demonstration of acetylcholinesterase activity $(\mathrm{AChE})^{17}$, the ileum of four animals were washed in PBS, dissected, fixed for 1 hour in $4 \%$ paraformaldehyde, incu- bated for 12 hours at $4^{\circ} \mathrm{C}$ in Krebs buffer with two ampoules of Hyaluronidase (Hyalozima, Apsen, São Paulo, Brazil) 2000 UTR and Tetraisopropil pirophosphoramide (isoOMPA; Sigma, Steinheim, Germany), then immersed for 24 hours at $4^{\circ} \mathrm{C}$ in a solution containing acetylthiocholine (Sigma, St. Louis, USA), phosphate buffer $0.1 \mathrm{M}$, sodium citrate $100 \mathrm{mM}$, copper sulphate $30 \mathrm{mM}$, distilled water, potassium ferricyanide $5 \mathrm{mM}$ and $3 \%$ Triton $\mathrm{X}-100^{\circledR}$ in Krebs, kept under constant agitation. Next the segments were fixed in buffered formaldehyde solution for 2 hours, dehydrated in absolute alcohol, diaphanized and mounted.

The whole-mounts prepared from the different techniques were dissected under stereomicroscope using transillumination through the removal of the mucosa and the submucosa. Then they were dehydrated in ascending series of ethylic alcohol, diaphanized in xilene and mounted on slices with permount ${ }^{\circledR}$ synthetic resin (FisherChemical, New Jersey, USA).

The quantitative analysis was carried out with all the techniques in the antimesenteric $\left(120^{\circ}\right.$ to $\left.240^{\circ}\right)$, intermediate $\left(60^{\circ}\right.$ to $120^{\circ} ; 240^{\circ}$ to $\left.300^{\circ}\right)$ and mesenteric $\left(0^{\circ}\right.$ to $60^{\circ}$ and $300^{\circ}$ to $360^{\circ}$, considering as $0^{\circ}$ the mesenteric attachment ${ }^{11}$ ) regions. The neurons were counted under an Olympus BX40 microscope with 40X objective. In each whole-mount 40 microscopic fields were counted in each of the aforementioned regions. Half-seen neurons were counted in alternate fields. The area of each microscopic field was $0.224 \mathrm{~mm}^{2}$.

The analysis were carried out at the Laboratory of Enteric Neurons of the Departament of Morphophysiological Sciences at the State University of Maringá.

The mean, standard deviation and variation coefficient of the data obtained were calculated. After assuring, through the variation coefficient, that the spreading of the data was small, and thus the mean was a very good representative of the values, the means were compared using the test $t$ of Student for unpaired data. The significance level adopted was $5 \%$.

\section{RESULTS}

The general arrangement of the myenteric plexus did not vary as a function of the regions of the circumference of the ileum (mesenteric, intermediate and antimesenteric).

The neuronal cell bodies were predominately clustered in ganglia which were often elongated with the largest axis circularly oriented (Fig 1).

With the histoenzymologic techniques of NADPH$\mathrm{d}$ and acetylcholinesterase we verified that the ganglia were interconnected both circularly and longitudinally by thick bundles of nerve fibers (primary bundles) forming a wide network. Thinner bundles were also observed (secondary bundles) connecting the primary bundles with each other, and many tiny bundles and even isolated nerve fibers (terciary 


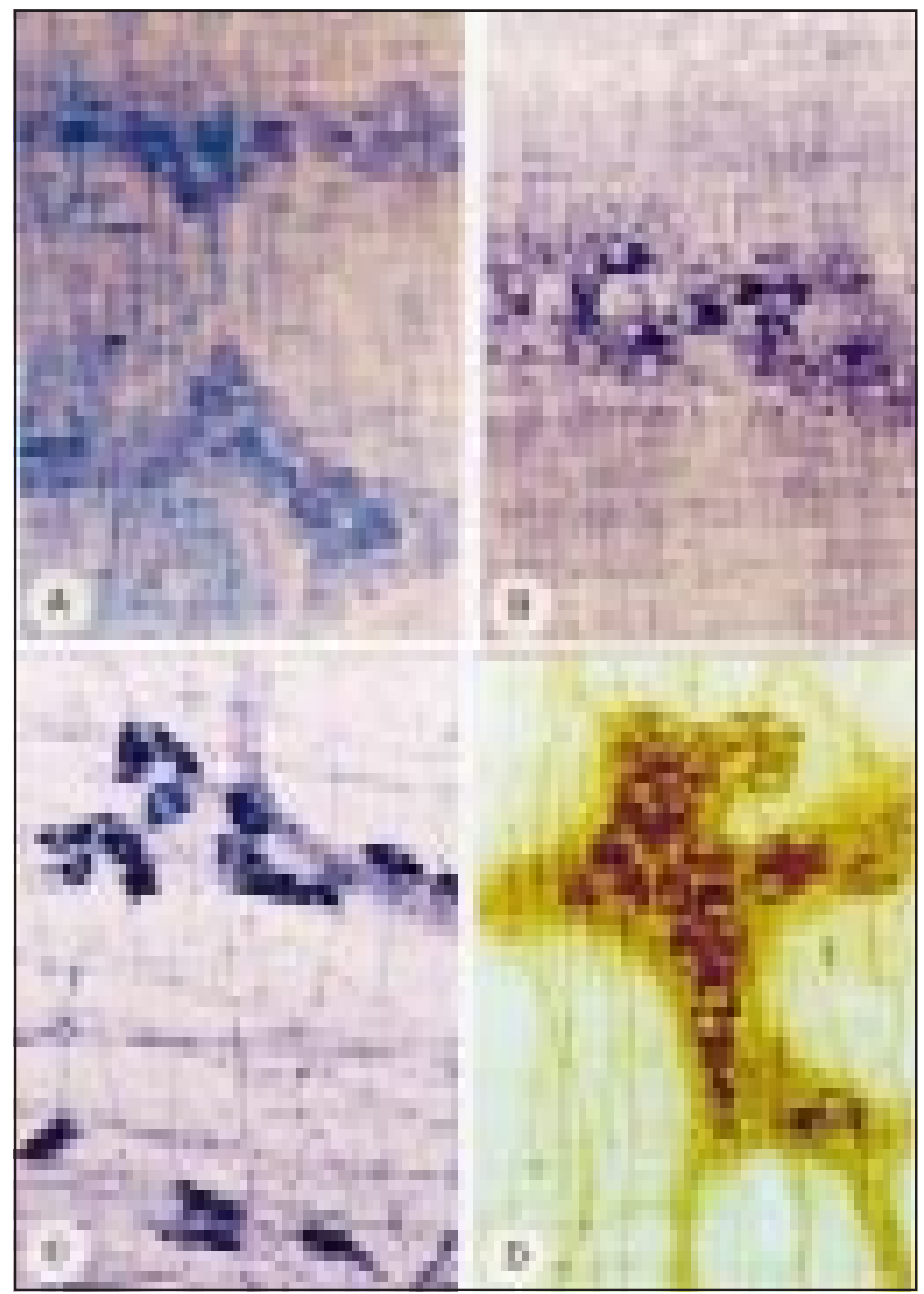

Fig 1. Whole-mounts evidencing neurons of the myenteric plexus of the ileum of rats. A) Giemsa staining; B) NADH-d histochemistry; C) NADPH-d histochemistry; D) Acetylcholinesterase histochemistry. 306X.

bundles) connected different elements of the myenteric plexus.

The density of neuronal cell bodies in the myenteric plexus varied according to the region of the intestinal circumference. In the region next to the mesenteric attachment (mesenteric region) the largest neuronal density was observed, while in the opposite region (antimesenteric region) the smallest density was verified. The mean number of neurons of the myenteric plexus in the mesenteric, intermediate and antimesenteric regions is presented in Table 1.
On the whole-mounts stained with Giemsa, the ganglia were composed of many neurons densely packed (Fig. 1A). With the NADH-d technique, the neurons were more sparse (Fig. 1B) with larger gaps among the cell bodies than those seen with the Giemsa technique. With the NADPH-d technique, wide spaces were observed in the ganglia, the neurons were sparsely distributed and most of them were peripheral in the ganglion (Fig. 1C). The highly reactive $\mathrm{AChE}$-positive neurons were frequently centrally located in the ganglion (Fig. 1D). 
Table 1. Frequency of neurons in the myenteric plexus found in $8.96 \mathrm{~mm}^{2}$ in the mesenteric, intermediate and antimesenteric regions of the ileum of rats aging seven months employing different techniques of neuronal staining.

\begin{tabular}{|c|c|c|c|c|}
\hline Technique & Number of animals & $\begin{array}{c}\text { Mesenteric } \\
\left(\text { Mean } n^{\circ} . \pm \text { s.d. }\right)\end{array}$ & $\begin{array}{c}\text { Intermediate } \\
\text { (Mean } n^{\circ} . \pm \text { s.d.) }\end{array}$ & $\begin{array}{l}\text { Antimesenteric } \\
\text { (Mean } \mathrm{n}^{\circ} . \pm \text { s.d.) }\end{array}$ \\
\hline Giemsa & 5 & $2144,40^{\mathrm{a} 1} \pm 161,05$ & $1790,60^{\mathrm{b} 1} \pm 128,24$ & $1647,00^{c 1} \pm 76,67$ \\
\hline $\mathrm{NADH}-\mathrm{d}$ & 5 & $1657,80^{\mathrm{a} 2} \pm 88,23$ & $1265,20^{\mathrm{b} 2} \pm 41,17$ & $981,80^{c 2} \pm 68,04$ \\
\hline NADPH-d & 4 & $473,80^{\mathrm{a} 3} \quad \pm 19,62$ & $371,30^{\text {b3 }} \pm 27,84$ & $298,50^{c 3} \pm 22,75$ \\
\hline ACHE & 4 & $905,25^{\mathrm{a} 4} \quad \pm 22,40$ & $770,25^{\mathrm{b} 4} \pm 33,12$ & $704,50^{\mathrm{b} 4} \pm 69,38$ \\
\hline
\end{tabular}

Mesenteric region: $0^{\circ}-60^{\circ}$ and $300^{\circ}-360^{\circ}$. Antimesenteric region: $120^{\circ}-240^{\circ}$. Intermediate region: $60^{\circ}-120^{\circ}$ and $240^{\circ}-300^{\circ}$, considering the mesenteric attachment as $0^{\circ}$. Means followed by the same letter in the same row do not differ statistically at the significance level of $5 \%$. Means followed by the same number in the same column do not differ statistically at the significance level of $5 \%$.

\section{DISCUSSION}

The circular orientation of the largest axis of the ganglia of the myenteric plexus observed with the techniques employed in this work agrees with the findings in the ileum of guinea-pigs with methylene blue $^{1}$, in the ileum of rats with NADH- $d^{5}$, in the small intestine of guinea-pigs with cuprolinic blue ${ }^{10}$, and in the ileum of mice with Giemsa and $\mathrm{ACHE}^{18}$, but disagrees with the description of a predominately longitudinal arrangement found in the ileum of rats with NADH-d and NADPH-d ${ }^{12}$.

The density of neurons in the mesenteric region of the ileum of rats was not discussed in the literature, possibly because the region near the insertion of the mesentery is much vascularized and rich in adipocytes, thus posing difficulties to the microdissection and elaboration of whole-mounts, as observed in the duodenum ${ }^{19}$ and colon of rats ${ }^{11}$. Nevertheless, in the terminal portion of the ileum the density of adipocytes was not great enough to interfere with the neuronal staining, permitting the evaluation of this region. Independently of the technique employed we verified that the mesenteric region had the largest neuronal density, possibly because it possesses neurons which promote the innervation of the smooth muscle fibers of the intestinal wall plus those which innervate the rich vascular plexus that penetrates the intestinal wall through the mesentery to irrigate it or leave the intestine to drain it.

We verified that in the ileum the more distant from the mesenteric attachment the observations are made the smaller is the neuronal density, being the region just opposite the mesentery root the least occupied by neurons. In studies in the colon of rats a larger number of neurons in the intermediate than in the antimesocolic region was observed; this difference was attributed to the presence of the thick layer of muscle fibers found in the intermediate region which would require a larger number of neurons to innervate it ${ }^{11}$.

Differences on the neuronal density in the myenteric plexus in distinct regions of the circumference of a given intestinal segment were also found in the large intestine of guinea-pigs ${ }^{1}$, colon of guineapigs $^{20}$, ileum of chickens ${ }^{4}$ and middle region of the small intestine of rats ${ }^{6}$.

With the Giemsa technique we found the following neuronal means in an area of $8.96 \mathrm{~mm}^{2}$ : mesenteric region 2144.40; intermediate region 1790.60; antimesenteric region 1647.00. Assuming that this technique evidences all the neurons once the staining results from the affinity of methylene blue for poliribosomes and all neurons, whatever their physiologic features, have these organelles we would have then the total number of neurons.

The NADH-d-positive neurons, relative to those evidenced with the Giemsa technique, represented $77.31 \%$ in the mesenteric region, $70.65 \%$ in the intermediate region and $59.61 \%$ in the antimesenteric region.

The smaller proportion of NADH-d-positive neurons relative to the population evidenced by the Giemsa technique was also observed by others ${ }^{11,19}$.

We verified with the NADH-d technique relatively wide spaces among the neuronal cell bodies composing the ganglia of the myenteric plexus. Heinicke et al. ${ }^{9}$ argue that these spaces could be occupied by small neurons which are not stained. 
We agree with Sant'Ana et al. ${ }^{11}$ that in spite of the NADH-d technique not evidencing all the neurons, it do stains neurons with greater activity of this enzyme. In experiments involving comparison of animals groups subjected to different treatments, it allows the evaluation of metabolic increase or decrease through the number of stained neurons. It is necessary however, to be rigorous with the incubation time, once prolonged exposures would allow that even neurons of low metabolic rate formed formazan granules in amounts large enough to be evidenced, with the handicap that other cells such as the enteric glia and muscle fibers would also be stained $^{9,11,21}$.

The NADPH-d-positive neurons, relative to those evidenced with Giemsa, represented in the mesenteric region $22.09 \%$, in the intermediate region $20.74 \%$ and in the antimesenteric $18.12 \%$. In the ileum of rats, $24.0 \%$ of NADPH-d-positive neurons were found relative to those evidenced with neutral red $^{22}$, but the ileal portion or the region of circumference studied is not referred to.

Although it does not stain all the neuronal population, the histochemistry of the NADPH-d have been largely employed in the last years, because several studies indicate that the neurons which it evidences express the enzyme nitric oxide synthase (NOS) ${ }^{23,24}$, and thus may use nitric oxide as a neurotransmitter, being relaxation-promoting neurons, or inhibitory interneurons of the myenteric plexus ${ }^{12}$. The coexistence of vasoactive intestinal peptide (VIP) and NOS (evidenced by the NADPH-d) in neurons of the myenteric plexus suggests that nitric oxide (NO) and VIP can act as inhibitory, nonadrenergic noncholinergic (NANC) neurotransmitters ${ }^{24,25}$. Recently it was found that all the neurons immunoreactive for VIP are NADPH-d-positive, but most of the NADPH-dpositive neurons are not immunoreactive for VIP24.

In the ileum of adult rats the proportion of NADPH-d-positive neurons relative to the NADH-dpositive neurons is $22.0 \%{ }^{12}$. In this experiment this neuronal subpopulation, when compared with the $\mathrm{NADH}$-d-positive neurons, represented in the mesenteric region $28.58 \%$, in the intermediate $29.35 \%$ and in the antimesenteric $30.40 \%$.

The AChE-positive neurons, relative to those stained with Giemsa, represented in the mesenteric region $42.21 \%$, in the intermediate $43.02 \%$ and in the antimesenteric $42.77 \%$. In five-month-old mice ${ }^{15}$ and in the rodent Calomys callosus ${ }^{26}$, it was observed that most of the neurons in the myenteric plexus, although not counted, had acetylcholinesterase activity, verified through reactions of different intensities exhibited by the neurons.

Through the use of antibodies raised against choline acetyltransferase, the enzyme catalyzing the synthesis of acetylcholine, it is being stablished the presence and the number of cholinergic neurons in the enteric nervous system, which in the guinea-pig small intestine would represent about $20.0 \%$ of the total neuronal population ${ }^{27}$. This proportion is significantly smaller than the proportion of acetylcholinesterase-positive neurons found in this work. This difference, in addition to the species-specific variations, could be related to the fact that many acetylcholinesterase-positive neurons are not necessarily cholinergic and that the presence of this enzyme on their cell bodies or extensions could indicate heteroregulation of cholinergic neurons.

The knowledge of the complex and varied cytoarchitecture of the myenteric plexus is also fundamental for the design of experiments on intestinal innervation. Quantitative determinations of the distribution of the neurons in the myenteric plexus provide information for the functional studies of intestinal motility $4,27,28$. The variation in the neuronal density verified around the intestinal circumference with the four techniques employed makes it clear that no matter which technique is used to stain the neurons, it is essential to set the region where the countings are made. When control and experimental groups are used the neglection of these aspects can give misleading results. Supposing an hypotetical situation in which a group of animals received a treatment that could have altered the number of neurons but did not do it; if the investigator, during sample collection or neuronal counting, privileged in the control group the mesenteric region and in the experimental one the antimesenteric, possibly would erroneously conclude that the condition led to a significant decrease in the number of neurons.

\section{REFERENCES}

1. Irwin DA. The anatomy of Auerbach's plexus. Am J Anat1931;49:141-165.

2. Matsuo HA. Contribution on the anatomy of Auerbach's plexus. Jpn J Med Sci Anat 1934;.4:417- 428

3. Gabella G. Neuron size and number in the myenteric plexus of the newborn and adult rat. J Anat 1971;109:81-94.

4. Ali HA, McLelland J. Neuron number in the intestinal myenteric plexus of the domestic fowl (Gallus gallus). Zbl Vet Med C Anat Histol Embryol $1979 ; 8: 277-283$.

5. Santer RM, Baker DM. Enteric neuron numbers and sizes in Auerbach's plexus in the small and large intestine of adult and aged rats. J Auton Nerv Syst 1988;25:59-67.

6. Santer RM. Survival of the population of NADPH-diaphorase stained myenteric neurons in the small intestine of aged rats. J Auton Nerv Syst $1994 ;$ 49:115-121. 
7. Natali MRM, Miranda-Neto MH. Effect of maternal proteic undernutrition on the neurons of the myenteric plexus of the duodenum of rats. Arq Neuropsiquiatr 1996;54:273-279.

8. Romano EB, Miranda-Neto MH, Cardoso RCS. Preliminary investigation about the effects of the streptozotocin-induced chronic diabetes on the nerve cell number and size of myenteric ganglia in rat colon. Rev Chil Anat 1996;14:139-145.

9. Heinicke EA, Kiernan JA, Wisjsman J. Specific, selective, and complete staining of neurons of the myenteric plexus, using cuprolinic blue. J Neurosci Methods 1987;21:45-54.

10. Karaosmanoglu T, Aygun B, Wade PR, Gershon M. Regional diferences in the number of neurons in the myenteric plexus of the guinea pig small intestine and colon: an evaluation of markers used to count neurons. Anat Rec 1996;244:470-480.

11. Sant'ana DMG, Miranda-Neto MH, Souza RR, Molinari SL. Morphological and quantitative study of the myenteric plexus of the ascending colon of rats subjected to proteic desnutrition. Arq Neuropsquiatr 1997;55:687-695.

12. Wilhelm M, Bátori Z, Pásztor I, Gábriel R. NADPH-Diaphorase positive myenteric neurons in the ileum of guinea-pig, rat, rabbit and cat: a comparative study. Eur J Morphol 1998;36:143-152.

13. Miranda-Neto MH, Molinari SL, Stabille SR, Sant'Ana DMG, Natali, MRM. Morphologic and quantitative study of the myenteric neurons of the jejunum of malnourished rats (Rattus norvegicus). Arq Neuropsiquiatr 1999;57:387-391.

14. Barbosa AJA. Técnica histológica para gânglios nervosos intramurais em preparados espessos. Rev Bras Pesqui Med Biol 1978;11:95-97.

15. Gabella G. Detection of nerve cells by histochemical technique. Experientia 1969;25:218-219.

16. Scherer-Singler U, Vincent SR, Kimura H, McGeer EG. Demonstration of a unique population of neurons with NADPH-diaphorase histochemistry. J Neurosci Methods 1983;9:229-234.
17. Karnovsky MJ, Roots L. A "direct-coloring" thiocholine method for cholinesterases. J Histochem Cytochem 1964;12:219-221.

18. Bor-Seng-Shu E, Chadi G, Bor-Jiun-Shu F, Ferraz-de-Carvalho CA, De-Souza RR Myenteric neurons of the mouse small intestine. Morphometry and acetylcholinesterase activity. Braz J Med Biol Res 1994;27:101-108.

19. Natali MRM. Estudo morfoquantitativo e ultra-estrutural do plexo mientérico do duodeno de ratos (Rattus norvegicus) adultos submetidos a carência protéica. Tese de Doutorado. Instituto de Biociências de Botucatu, UNESP. Botucatu 1999.

20. Gabella G. On the plasticity of form and structure of enteric ganglia. J Auton Nerv Syst 1990;30:59-66.

21. Young HM, Furness JB, Sewell P, Burcher EF, Kandiah CJ. Total numbers of neurons in myenteric ganglia of the guinea-pig small intestine. Cell Tissue Res 1993;272:197-200.

22. Cracco C, Filogamo G. Quantitative study of the NADPH-diaphorasepositive myenteric neurons of the rat ileum. Neuroscience 1994;61:.351-359.

23. Young HM, Furness JB, Shuttlewort CWR, Snyder SH. Co-localization of nitric oxide synthase immunoreactivity and NADPH-diaphorase in neurons of the guinea-pig intestine. Histochemistry 1992;97:375-378.

24. Toole L, Belai A, Burnstock G. A neurochemical characterisation of the golden hamster myenteric plexus. Cell Tissue Res 1998;191:385-394.

25. Aimi Y; Kimura H, Kinoshita T, Minami Y, Fujimura M, Vincent SR. Histochemical localization of nitric oxide synthase in rat enteric nervous system. Neuroscience 1993; 53:553-560.

26. Maifrino LBM, Prates JC, De-Souza RR, Liberti EA. Morphometry and acetylcholinesterase activity of the myenteric plexus of the wild mouse Calomys callosus. Braz J Med Biol Res 1997;30:627-632.

27. Sternini C. Structural and chemical organization of the myenteric plexus. Ann Rev Physiol 1988;50:81-93.

28. Furness JB, Costa M. The enteric nervous system. Edinburgh: Churchill Livingstone, 1987. 